THE ANNUAL LECTURE OF THE INSTITUTE FOR BIBLICAL RESEARCH, 1977*

\title{
PROPHECY, INSPIRATION, AND SENSUS PLENIOR
}

\section{By William Sanford LaSor}

The Institute for Biblical Research is committed to two main concepts. We are committed to rigorous scholarly methodology, and we are committed to the proposition that the old and New Testaments are the Word of God, the infallible rule of faith and practice. These two concepts - and I am sure that here I voice the testimony of each one of us - these two concepts keep us continually in a state of tension. So much is this true that at times, we must confess, we devote our scholarly activities to questions that do not directly involve our theological presuppositions. How easy it is to prepare a paper on "The Sibilants in Old South Arabic", or "The Masoretic Accents in Hebrew Foetry", or "The Version Quoted by the Author of Hebrews"! I have contributed my share of papers on such subjects, so what I say is not an attempt to ease my own conscience while making you squirm.

The Institute for Biblical Research, however, must exist for something more than secular scholarship. I am not too happy about that word "secular" for we have shifted its meaning greatly. The saecula are the ages, and secular scholarship should be scholarship that is intended for or concerns the ages. But we have made it. mean the opposite of "sacred". Secular scholarship may be biblical scholarship, in that it discusses some area that is derived from the biblical text or is in some way related to the biblical world of ideas, but it is nevertheless secular in that the methods and results are no different than they would be in nonbiblical scholarship. We, however, believe that the Bible is the Word of the living God. We believe that it is authoritative for our generation and for every generation. Therefore we dare not treat the Bible as we would treat any other book.

* Delivered at the Annual Meeting of the Institute for Biblical Research, San Francisco, 31 December 1977. 
While it is true that there is no special knowledge necessary for biblical studies, while it is true that we deny any esoteric key to Scripture, while it is true that we approach the Bible with the conviction that it means exactly what it says, it is not true that the Bible means nothing more than that. We are fully committed to the exegetical method commonly known as the "grammatico-historical method". We believe that the first step in biblical exposition is to discover as precisely as is humanly possible, given the data available to us in our day, what the passage meant to those who first heard or read the passage. But, as has been pointed out several times by recent scholars, if the passage that we are studying means nothing more when we have finished than it meant to the original audience, then it has only antiquarian interest. It is not the word of God to us. At most, it may be the meeting-ground where God confronts us, but the confrontation is in the existential moment, and not in the written word.

Therefore, in this the first of a series of papers to be presented to the Institute for Biblical Research by members of our fellowshif, I propose to deal with a subject which, in my opinion, forces us to grapple with the divine as weil as the human element in the Word of God. My subject, "Prophecy, Inspiration, and Sensus Plenior", deals with biblical prophecy. By this term I mean the phenomenon that is presented in the Bible, when one of God's servants, under the inspiration of God's Spirit, confronts a person or group of persons with a message suited to that rarticular time and circumstance. By the term "inspiration", I intend to define prophecy as something quite more than human wisdom or insight. The prophet was not merely an astute observer of human personality and international politics. He was indeed a person of his time, with no special knowledge other than that which was available to others in his circle. But his relationship to God was such that God could give him some revelation that would be God's word to those people. To recover that message, we make full use of grammaticohistorical exegesis. By the third part of my title, sensus plenior, which I shall attempt to define more precisely in this parer, I intend to discuss the fuller meaning of a passage, the "something more" that was given by God in the divine inspiration, that makes the message equally valid as the word of cod to succeeding generations. 
It is this "something more" that gives us problems in objective control. Any one of us, with our scholarly training and experience, can take a passage of scripture and arrive at an exegesis that is reasonably accurate and complete. I shall not insult your intelligence by labouring this point. But where do we go from there? From that given passage, what is God's timeless message? What is cod's word to us today? How can we be sure that it is God's word, and not just some net idea of mine that I am imposing on Scripture? It is to this complex problem that I invite your attention.

\section{Levels of Meaning}

(i) The Literal Meaning. For any given passage of Scripture, as for any other writing, there is a literal meaning. It is clear to all of us, I am sure, that this term does not mean simply a one-for-one transfer of the meanings of words. Rather, it includes figures of speech, literary genres, and any other elements that are necessary to understand the passage in precisely the same way as it was intended by the original speaker or writer and as it was understood by any person of normal intelligence and perspicuity in the time and place where the message was first given. In other words; the literal meaning is that meaning that we should arrive at by careful grammatico-historical exegesis. Perhaps two or three illustrations will make my point clear.

In Genesis 12:4 we read, "And Abram was seventy-five years old when he departed from Haran". With a Bible dictionary, a Bible atlas, and a knowledge of the meanings of Hebrew words and syntax, we can derive the literal meaning. Someone named Abram, a male, left a place called Haran at an advanced age.

In Eosea 11:3 we read, "Yet it was I who taught Ephraim to walk". Now we find that the literal meaning is something more than the sum of the words. In context, the speaker is Yahweh, the God of Israel, "Ephraim" is not the person by that name, nor the tribal territory, but either the northern kingdom or, more likely in view of the first verse, both Israel and Judah. The verb "to walk" may convey the fact that Yahweh had given the training necessary for the young nation in its earliest childhood, or it may apply specifically to the revealed will in the Torah. There are a few points where we may differ, but something like this is the literal meaning. 
In Psalm 23:1 we read, "The Lord is my shep̣herd". This is poetry, and figures of speech are used. The literal meaning does not tell us that Yahweh is a shepherd and the Psalmist is a sheep. It describes a relationship under the figure of a shepherd and his flock. This is still the literal meaning. It is precisely what the author intended and what the initial audience understood.

(ii) The Spiritual Meaning. Since God is spirit, and since our relationship with $\mathrm{Him}$ is a spiritual relationship, there is spiritual significance in the scripture. It is for this reason that cod's people have referred to the Scripture as God's Word, and have always searched it for spiritual truth. Specifically, we refer to the Word of God as "the infallible rule of faith and practice". I am not personally involved in the purely literal meaning, whether it concerns Abram leaving Haran, or Israel receiving God's discipline, or David singing about Yahweh as his Shepherd. But I am personally involved in the spiritual truth to be found in such passages.

But to discover the spiritual meaning involves more than grammatico-historical exegesis. At this point we enter the long and involved history of interpretation. Again, I am sure that we all have considerable understanding of the various theories that have been applied. I am not sure, however, that we all agree on the terminology that we use. What Martin Luther, for example, calls the "historical, simple, and literal sense" of a passage,/1/ seems to me to be the allegorical. And what I understand as typology another scholar calls "allegorical". Even sensus plenior has been grouped with typology under the heading of allegory. So let me define what I mean by the spiritual sense: the spiritual sense is the timeless truth in a given passage of Scripture. Let me try to illustrate this definition.

1. See Luther on Gen. 28:12-14, Luther's Works, ed., Jaroslav Pelikan, Vol. 5, lectures on Genesis, Chaps. 26-30, Concordia Publishing House, st. Louis (1968) 223. 
In the passage in Genesis 12, about Abram leaving Haran, I find, when I consider the context, that the underlying spiritual message is God's sovereign election, specifically His call to Abram to go to the Iand that cod would show him, and in the portion that I quoted, I find the spiritual lesson that a man of faith responds in obedience to God's call, regardless of time or circumstances. In Hosea 11:3, again taking into consideration the context, I find the spiritual truth that Yahweh's sovereign choice is based on His love, and His revelation of His will to His people arises out of that love and looks for a response of loving obedience. In Psalm 23 I find the spiritual truth that because of the Lord's gracious provision for the needs of His people, any one of His people can rest confidently in His loving care.

You will notice that in each case I have derived the spiritual meaning from the passage under consideration, starting with the literal meaning and moving to a deeper level of timeless truth. There may be points at which we will differ in the ways we attempt to express the spiritual truth, but I believe that you will agree that I have not introduced any fanciful system of interpretation nor have I imposed a meaning on the text. I think you will also agree that if this is all the meaning that we can derive from the passages of Scripture, we have something far different, or far less, than the New Testament writers found in the old Testament. We may have valuable spiritual truths that can be built into a system of biblical theology, but we do not seem to have anything that approaches the significarce of the words of our Lord when He spoke of the Scriptures being "fulfilled".

(iii) The Sensus Plenior. I therefore suggest that there is yet another level of meaning in the scriptures, which I shall call sensus plenior, which means literally "the fuller sense". 
The theologian who has done the most to clarify the concept of sensus plenior is Raymond E. Brown./2/ He defines sensus plenior as follows:

The sensus plenior is that additional, deeper meaning, intended by God but not clearly intended by the human author, which is seen to exist in the words of a Biblical text (or group of texts, or even a whole book) when they are studied in the light of further revelation or development in the understanding of revelation./3/

I an not completely happy with this definition, and I shall try to clarify my concept in the remainder of this paper. But this definition is a satisfactory starting point.

\section{The Sensus Plenior, Its Discovery and Its Use}

(i) Sensus Plenior and Exegesis. One of the principal objections to the concept of a sensus plenior may be stated in the following way: If it is a deeper meaning, intended by God but not clearly intended by the human author, then we cannot discover it by using grammaticohistorical exegetical methods. The purpose of exegesis is to discover what the author intended - but in the sensus plenior we are seeking to discover something which the author did not (clearly) intend. The objection is indeed valid, at least on the surface. But let us go back again to the Scripture and see whether Scripture itself recuires a sensus filenior.

(ii) Prophecy and Fulfilment. Prophecy, using the term in its biblical sense, is the presentation of God's message to a person or group of persons in a given historical situation. Since that revelation of God's

2. R. E. Brown, "The History and Development of the Theory of a Sensus Plenior", Catholic Biblical Quarterly 15 (1953) 141-162; The Sensus Plenior of Sacred Scripture (S.T.D. dissertation; Baltimore: St. Mary's University, 1955) $161 \mathrm{pp} . ;$ "The Sensus Plenior in the Last Ten Years", CBO 25 (1963) 262285.

3. The Sensus Plenior of Sacred Scripture, 92. 
will quite often includes some future development, such as punishment for disobedience, blessing for faithfulness, or the achieving of God's ultimate purpose in some future time, we frequently refer to the "fulfilment" of prophecy. The term is good, but it is sometimes misunderstood.

One of the sources of misunderstanding is the common tendency to associate "prediction" and "fulfilment". There is a vast difference, qualitatively, between prediction and prophecy. Prediction is the simple foretelling of a coming event or sequence of events. Usually there is no connection between the predictor and the event, and the "fulfilment" is either pure coincidence or some kind of prescience (and I make no attempt to explain it further in this paper). Prophecy in the biblical sense, however, is not merely the prediction of a future event; rather, it is the revelation of God's purpose in the present situation and in its on-going character. God's redemptive purpose dces not consist of a huge number of discrete decisions and actions. It is an age-long outworking of His will. What $\mathrm{He}$ is about to do He reveals to His servants the prophets. At any given point in the history of God's revelatory and redemptive activity, He is fulfilling His purpose. It is not yet complete - or, to use another word, "full". It is being filled. Prophecy, in the sense that it reveals some part of God's redemptive purpose, is capable of being filled, of achieving a fullness, so that when it is filled full it is fulfilled. If we understand prophecy in this sense, we no longer ask the question, "Is prophecy capable of more than one fulfilment?". It is capable of more and more filling until it is entirely fulfilled.

It is precisely in this context that I prefer to use the term sensus plenior. If I am correct in defining biblical prophecy as the revelation of some part of God's redemptive purpose as it relates to a specific situation, then that passage of Scripture contains a potential fullness; that situation is somehow organically related to God.'s purpose, and the fullness of meaning can be discovered by attempting to relate the situation and the prophecy to the on-going redemptive purpose of God. This fuller meaning is the sensus plenior of the passage. In one sense, it lies outside and beyond the historical situation of the prophet, and therefore it cannot be derived by grammatico-historical exegesis. But in 
another sense, it is part of the history of redemption, and therefore it. can be controlled by the study of Scripture taken in its entirety.

Perhaps an illustration will make clear what I am trying to say. An ordinary seed contains in itself everything that will develop in the plant or tree to which it is organically related: every branch, every leaf, every flower. Yet no amount of examination by available scientific methods will disclose to us what is in that seed. However, once the seed has developed to its fullness, we can see how the seed has been fulfilled. The illustration breaks down at a certain point, for we do not yet have the complete fulfilment of Scripture. We have to work with what we have, namely a partially completed redemptive work of God. Even so, we have sufficient revelation in the scriptures to keep our interpretations of sensus plenior from becoming totally subjective.

\section{Some Illustrations of Sensus Plenior}

(i) Genesis 3:15. Let me turn to Genesis 3:15, often called the "protevangelion", or the first enunciation of the gospel. It is part of the curse which God pronounced after the Adamic couple yielded to the temptation suggested by the serpent. It reads as follows :

I will put enmity between you and the woman, and between your seed and her seed;

he shall bruise your head, and you shall bruise his heel.

To suggest that this passage is simply an explanation of why women hate snakes is ridiculous. The literal meaning seems to say simply that there is hostility between the woman and the serpent, and between the woman and the serpent, and between the descendants of the two, and that this continuing hostility would result in the bruising of the serpent's head by the woman's offspring, while at the same time the woman's offspring would be wounded in the heel by the serpent. In cther words, someday a human being would step on a serpent, mortally wounding the serpent and being wounded in the process. Even if we spiritualize this, we do not exhaust its meaning, for all it seems to say 
is that we must seek to crush the source of our temptations.

The entire account (Genesis 3:14-19) contains two interwoven strands, one of which speaks of defeat, suffering, toil, and death, while the other speaks of future generations, of provision of food and sustenance of life, and the ultimate triumph over the serpent. The larger context tells of the satanic origin of the temptation (using the word "satanic" in its basic meaning of opposed to God's revealed will), and how yielding to it brought death upon the human race. The rest of the Bible tells how cod is working to remove the results of this sin, and accomplish His redemptive purpose. The sensus plenior of the passage then can be discovered. I do not find the expression "the seed of the woman" to be a prophecy of the Virgin Mary or the Virgin Birth, but I do find the fullness of meaning in some as-yet-unspecified member of the human race who would destroy the satanic serpent, thus playing a key role in God's redemptive plan. In that sense, the passage is indeed the first enunciation of the good news.

(ii) Hosea 11:1. The next passage to which I turn your attention is the well-known prophecy of Hosea, "Out of Egypt I have called my son" (11:1). To complicate our exegesis, Matthew has quoted this passage (Matt. 2:15), and says that it was fulfilled by the historical situation that arose when the Holy Family took the Christ Child to Egypt to escape the slaughter of the innocents commanded by Herod. The literal meaning of Hosea 11:1, however, does not seem to give us any basis for such a fulfilment. Hosea is clearly talking about the exodus of Israel from Egypt: "When Israel was a child I loved him, and out of Egypt I called my son." If there is any lingering desire on our part to make this apply to Jesus, we are suddenly faced by the words that follow immediately: "The more I called them, the more they went from me; they kept sacrificing to the Baals, and burning incense to idols" (Hos. 11:2). Even the spiritual meaning does not help us, for it seems to tell us that God is faithful to watch over His people and to rescue them from cruel oppression, even though they do not appreciate what He has done for them and turn to other gods. 
But in the historical sequence of events as unfolded by the Scriptures, we begin to see a deeper meaning, a sensus plenior. When God called the Hebrew people, the children of Israel, out of Egypt, He was in fact working out His redemptive plan. This had been revealed in part to Abraham, when God told him that his descendants would be slaves in another land. It was also a step in the fulfilment of the promise to give Abraham's descendants the land of the Canaanites. If God had not brought Israel out of Egypt, there would have been no Israelite nation, no Davidic line, no prophets, and no Messiah. Jesus could not have been born to Mary, and there would have been no redemptive work on Calvary's cross. Now I am not suggesting that all of this was in Hosea's mind when he spoke the words. He was inspired by God's Spirit, however, and the Spirit led him to express his words in a form that was capable of a fuller meaning. The fullness of that prophetic word was seen by Matthew, and he found the fulfilment in Christ.

(iii) Micah 5:2. Let me take one more illustration, namely the Bethlehem-prophecy of Micah 5:2 (5:1 MT).

But you, o Bethlehem Ephrathah,

Who are little to be among the clans of Judah,

from you shall come forth for me

one who is to be ruler in Israel,

whose origin is from of old,

from ancient days.

The prophecy was spoken prior to the Assyrian invasion (cf. 5:5). The scattering of Israel is in view $(5: 7)$. The people are filled with fear (4:9). The prophet not only deals with their sin, but he offers some promise of deliverance $(4: 10)$, and he by implication offers

assurance that the Davidic line will again rule Israel. of course, he does not mention the Davidic line, but it is clearly implicit in the context. The ruler not only comes from Bethlehem Ephrathah, the ancestral home of the Davidic dynasty, but his origin is. "from of old, from ancient days" - in other words, it will not be a new dynasty, but a continuation of the old. Spiritually, the verse could be applied to any time of insecurity and would remind God's people that He is still in charge, and that His will will certainly be done. 
But there is a sensus plenior that can be seen as we put this prophecy in the context of the on-going redemptive purpose of God. The ultimate defeat of the enemies of God's people is in sight, along with a ruler who provides security and sufficiency for His people (5:3-4). The early Church saw a fulfilment of this prophecy in Jesus and His birth in Bethlehem. Some of us look forward to a more complete fulfilment when the Son of Man comes in His glory to establish His messianic kingdom.

\section{Conclusion and Implications}

Something like a sensus plenior is required by many portions of Scripture, possibly by all of scripture. BY the very nature of God's revelatory and redemptive activity, the ultimate purpose of God is contained in the process, and as the redemptive activity proceeds to its fullness, so the revelatory activity takes on increasing content. The prophetic word ever takes on fuller meaning, but it is not completely fulfilled until it is filled full.

The quest for a sensus plenior is part of the process of discovering the fullness of God's purpose in His revelation. It is the recognition that at any moment He has the end in view, and in any generation He has future generations in His purpose. The very inscripturation of the prophetic word implies as much, for unless the prophetic word was intended for future generations there was no need to cause it to be written down.

There are guidelines to be observed in our quest for the sensus plenior. First of all, it must always begin with the literal meaning of the text. Sensus plenior is not a substitute for grammatico-historical exegesis, but a development from such exegesis. It is not a reading into the text of theological doctrines and dogmas; rather it is a reading out of the text the fullness of meaning required by God's complete revelation. Finally, we must reject any notion that the sensus plenior is derived from any mystical or esoteric source other than the scriptures. A person who is spiritually minded may get more out of the Scriptures, simply because he or she puts more into the study of them and is listening more keenly for God's word. But that person does not have any additional special revelation. The Scriptures of the old and New Testaments are the only infallible 
rule of faith and practice. It is from the Word alone that we have God's revelation, and from the Word alone that we can discover any fuller meaning. The concept of sensus plenior helps us to see more of God's revealed truth in His Word. 